®Ю. Б. Якимчук

ДВНЗ «Тернопільський державний медичний університет імені I. Я. Горбачевського МO3 Украӥни»

\title{
РІВЕНЬ ЕНДОГЕННОЇ ІНТОКСИКАЦІЇ В ЕКСПЕРИМЕНТІ НА ТЛІ РІЗНИХ ДОЗ МЕТОТРЕКСАТУ ТА ЗАХИСНА ДІЯ КАЛЬЦІЮ ФОЛІНАТУ
}

РІВЕНЬ ЕНДОГЕННОЇ ІНТОКСИКАЦІЇ В ЕКСПЕРИМЕНТІ НА ТЛІ РІЗНИХ ДОЗ МЕТОТРЕКСАТУ ТА ЗАХИСНА ДІЯ КАЛЬЦІЮ ФОЛІНАТУ. Нами було вивчено індекс ендогенної інтоксикації у 54 дослідних щурів на фоні одноразового та дворазового введення метотрексату в дозі 1 мг/кг на 3 та 7 доби. Досліджено захисну дію кальцію фолінату в дозі $0,1 \mathrm{мг/кг,} \mathrm{який} \mathrm{вводився} \mathrm{через} 24$ год після ін'єкції метотрексату. Одноразове використання метотрексату призводить до достовірного збільшення рівня токсичності плазми крові у щурів. Дворазове введення метотрексату погіршує еритроцитарний індекс інтоксикації. Використання кальцію фолінату показало достовірні результати зменшення ендогенної інтоксикації. Введення кальцію фолінату після кожної ін'єкції метотрексату дає достовірне зменшення цього показника і не залежить від одноразового чи дворазового введення цитостатика.

УРОВЕНЬ ЭНДОГЕННОЙ ИНТОКСИКАЦИИ В ЭКСПЕРИМЕНТЕ НА ФОНЕ РАЗЛИЧНЫХ ДОЗ МЕТОТРЕКСАТА И ЗАЩИТНОЕ ДЕЙСТВИЕ КАЛЬЦИЯ ФОЛИНАТА. Нами бЫЛО изучено индекс эндогенной интоксикации в 54 опытных крыс на фоне однократного и двукратного введения метотрексата в дозе 1 мг/кг на 3 и 7 сутки. Исследовано защитное действие кальция фолината в дозе $0,1 \mathrm{mr} / \mathrm{kг}$, который вводился через 24 ч после инъекции метотрексата. Одноразовое использование метотрексата приводит к достоверному увеличению уровня токсичности плазмы крови у крыс. Двукратное введение метотрексата ухудшает эритроцитарный индекс интоксикации. Использование кальция фолината указало на достоверные результаты уменьшения эндогенной интоксикации. Введение кальция фолината после каждой инъекции метотрексата дает достоверное уменьшение этого показателя и не зависит от одноразового или двукратного введения цитостатика.

THE LEVEL OF ENDOGENOUS INTOXICATION IN EXPERIMENTS ON DIFFERENT DOSES OF METHOTREXATE AND PROTECTIVE ACTION OF CALCIUM FOLINATE. We have studied the index of endogenous intoxication in rats in 54 researches during single and double use methotrexate at a dose of $1 \mathrm{mg} / \mathrm{kg}$ for 3 and 7 days. We have explored the protective effect of calcium folio (dose $0.1 \mathrm{mg} / \mathrm{kg}$ ), at $24 \mathrm{~h}$ after injection of methotrexate. One-time use of methotrexate leads to a significant increase of the level of toxicity in rat plasma. Two-time use of methotrexate intoxication make erythrocytic index worse. Using of calcium folio improves index endogenous intoxication and does not depends on a single or double entry cytostatics.

Ключові слова: метотрексат, індекс ендогенної інтоксикації, кальцію фолінат.

Ключевые слова: метотрексат, индекс эндогенной интоксикации, кальция фолинат.

Key words: methotrexate, endogenous intoxication index, calcium folio.

ВСТУП. Позаматкова вагітність (ПВ) - це вагітність, при якій імплантація заплідненої яйцеклітини відбулася поза порожниною матки. Найбільш часта локалізація ПВ - маткові труби [1, 3, 5].

Досліджувана патологія досі залишається актуальною. Від 6 до $10 \%$ пацієнток приймають у гінекологічний стаціонар з діагнозом «підозра на позаматкову вагітність» $[1,6]$.

Лікування хворих з позаматковою вагітністю включає два основні методи: хірургічний і консервативний $[4,6,8,12]$. Ряд авторів стверджує, що використання метотрексату внутрішньом'язово для консервативного лікування прогресуючої ПВ під контролем рівня хоріонічного гонадотропіну призводить до повноїдеструкції плідного яйця $[1,7,8,9]$.

Метотрексат (MTX) є класичним антагоністом фолієвої кислоти, яка використовується в лікуванні позаматкової вагітності (ПВ) протягом багатьох років. Пацієнтів з ПВ можна успішно лікувати метотрексатом згідно з протоколом № 676 МО3 України від 31.12.2004 року. МТХ може інгібувати нормальні клітини трофобласта і зменшити диференціацію та проліферацію цитотрофобласта [6, 7, 11]. Однак лабораторні дані говорять про те, що МTX може викликати токсичний вплив на організм [2, 10, 13]. Побічні ефекти метотрексату, як антагоніста фолієвої кислоти, системна токсичність обмежують терапевтичну цінність МTX, пов'язані з депресією кістково-мозкового кровотворення, токсичним впливом на слизові оболонки, печінку, легені та кістковий мозок [2, 6, 8, 14].

На нашу думку, було цікавим дослідити токсичний вплив метотрексату на експериментальних тварин залежно від дози та оцінити захисний ефект кальцію фолінату після одноразового та дворазового введення метотрексату на дослідних тварин.

МАТЕРІАЛИ ТА МЕТОДИ. Робота виконана на 54 лабораторних білих щурах, які утримувались у стандартних умовах віварію. Були відібрані статевозрілі невагітні самки 3 масою тіла $(220 \pm 5)$ г. Всі маніпуляції $з$ експериментальними тваринами проводили із дотриманням правил Європейської конвенції про захист хребетних тварин, що використовуються для дослідних та інших наукових цілей. Піддослідні тва- 
рини були розділені на такі групи: 9 груп по 6 тварин. До першої групи ввійшли 6 здорових статевозрілих невагітних самки. В дослідні групи ввійшли тварини, яким вводився метотрексат у дозі $1 \mathrm{мг/кг} \mathrm{внутрішньо-}$ м'язово. Рівень токсичності плазми визначався на 3 добу (друга група) та 7 добу (третя група). До четвертої та п'ятої груп увійшли тварини, які після одноразового введення метотрексату внутрішньом'язово в дозі $1 \mathrm{mг/кг} \mathrm{додатково} \mathrm{отримували} \mathrm{кальцію} \mathrm{фолінат}$ у дозі $0,1 \mathrm{мг/кг} \mathrm{через} 24$ год після першої ін'єкції, виведення $з$ експерименту, відповідно, на 3 та 7 доби. Щурам, які увійшли до шостоїта сьомої груп, вводився метотрексат двічі, через 7 днів після першої ін'єкції у вищезазначеній дозі, виведення з експерименту на 3 та 7 доби після останнього введення метотрексату. Щурам восьмої та дев'ятої груп вводили дворазово метотрексат та кальцію фолінат через 24 год після ін'єкції та визначали еритроцитарний індекс інтоксикації на 3 та 7 доби.

Токсичність плазми крові оцінювали за еритроцитарним індексом інтоксикації (Eil) [10]. Рівень токсичності плазми визначався на 3 та 7 доби після введення метотрексату.

Статистичну обробку результатів виконано у відділі системних статистичних досліджень ДВНЗ «Тернопільський державний медичний університет імені І. Я. Горбачевського МОЗ України» в програмному пакеті StatSoft STATISTICA.

РЕЗУЛЬТАТИ ДОСЛІДЖЕННЯ ТАЇХ ОБГОВОРЕННЯ. Аналізуючи отримані результати (рис. 1, табл. 1), звертає на себе увагу достовірна різниця між показниками контрольної групи щурів та дослідних. Порівнюючи еритроцитарний індекс інтоксикації у контрольній групі та при одноразовому введенні метотрексату на 3 та 7 доби зріс на $50 \%(79,25 \pm 1,01) \%$ та
$51,4 \%(80,00 \pm 1,41) \%, \quad p<0,001$ відповідно проти $(52,85 \pm 1,86) \%$ у щурів контрольної групи. Тоді як при використанні КФ (у 4 та 5 групах) цей показник зріс лише на $22,7 \%$ та $23,2 \%(64,84 \pm 1,51) \%$ та $(65,1 \pm 1,56) \%$, p<0,001 проти $(52,85 \pm 1,86) \%$ - у щурів контрольної групи). Відповідно, порівнюючи 2 та 3 групи 34 і 5 групами, еритроцитарний індекс зменшився при використанні КФ на $22,2 \%$ на 3 добу $((64,84 \pm 1,51) \%$ до $(79,25 \pm 1,01) \%, p<0,001)$ та на $22,9 \%$ на 7 добу $((65,1 \pm 1,56) \%$ до $(80,00 \pm 1,41) \%, p<0,001)$.

Повторне введення метотрексату у щурів приводило до ще більшого зростання рівня еритроцитарного індексу інтоксикації через 3 та 7 днів на 73,7 \% та $80,2 \%$ відповідно $(91,8 \pm 0,99) \%$ та $(95,24 \pm 1,42) \%$, проти $(52,85 \pm 1,86) \%, \quad p<0,001$ у щурів контрольної групи) та на $15,8 \%$ та $19,1 \%$, порівнюючи з одноразовим введенням $(p<0,001)$. Тоді як при використанні КФ (8 та 9 групи) цей показник зріс лише на $27,1 \%$ та $24,2 \%(67,15 \pm 0,94) \%$ та $(65,63 \pm 1,34) \%$, проти $(52,85 \pm 2,28) \%$, p<0,001 у щурів контрольної групи). Результати дослідження показали, що еритроцитарний індекс інтоксикації у 8 та 9 групах при використанні КФ у порівнянні до 6 та 7 групи зменшився на $26,85 \%$ на 3 добу $(64,84 \pm 1,51) \%$ до $79,25 \%$ p $<0,001)$ та на $31,09 \%$ на 7 добу $((65,10 \pm 1,56) \%$ до $(80,00 \pm 1,41) \%, p<0,001)$.

При вивченні показників одноразового (у 2 групі) та дворазового введення метотрексату при повторному введенні (у 6 групі тварин) виявили збільшення еритроцитарного індексу інтоксикації на 3 добу на $15,8 \%, p<0,001$, а на 7 добу (3 та 7 групи) відповідно - на 19,1\%, р<0,001; тоді як при використанні КФ на 3 добу (4 та 8 групи) цей показник збільшився всього на $4,8 \%, p>0,05$, та на 7 добу (5 та 9 групи) на $0,8 \%, p>0,05$.

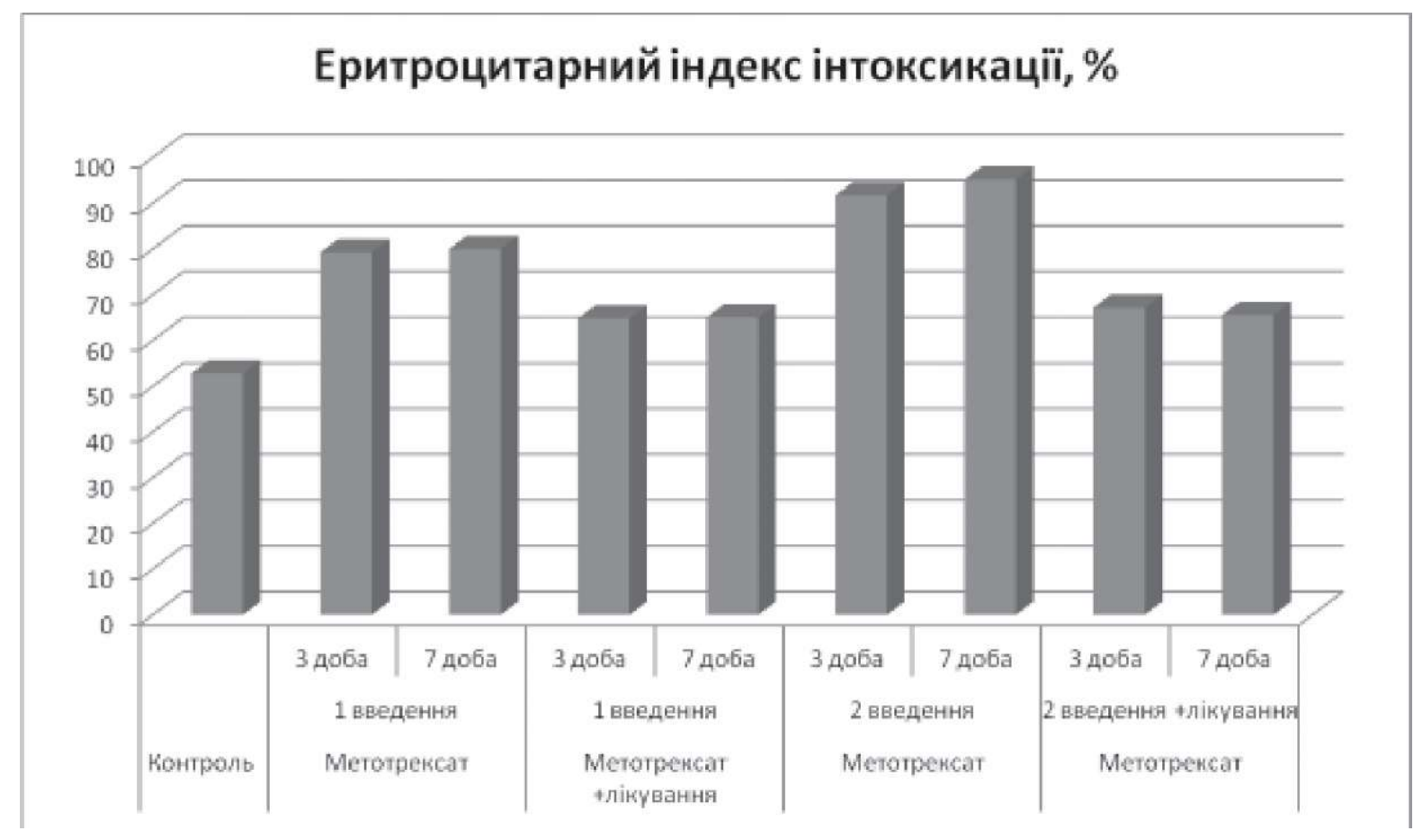

Рис.1. Графік зміни рівня Ell у щурів під впливом різних доз метотрексату. 


\section{Акушерство та гінекологія}

Таблиця 1. Вміст рівня еритроцитарного рівня інтоксикації у щурів залежно від дози метотрексату та використання кальцію фолінату

\begin{tabular}{|c|c|c|c|c|c|c|c|c|c|}
\hline \multirow[t]{2}{*}{ Показник } & \multirow[t]{2}{*}{ Контроль } & \multicolumn{2}{|c|}{$\begin{array}{r}\text { Метотрексат } \\
1 \text { введення }\end{array}$} & \multicolumn{2}{|c|}{$\begin{array}{c}\text { Метотрексат + лікуван- } \\
\text { ня КФ } 1 \text { введення }\end{array}$} & \multicolumn{2}{|c|}{$\begin{array}{c}\text { Метотрексат } \\
2 \text { введення }\end{array}$} & \multicolumn{2}{|c|}{$\begin{array}{c}\text { Метотрексат } \\
2 \text { введення + лікування } \\
\text { КФ }\end{array}$} \\
\hline & & 3 доба & 7 доба & 3 доба & 7 доба & 3 доба & 7 доба & 3 доба & 7 доба \\
\hline $\begin{array}{l}\text { Еритроцитар- } \\
\text { ний індекс ін- } \\
\text { токсикації, \% }\end{array}$ & $\begin{array}{l}52,85+ \\
1,86\end{array}$ & $\begin{array}{c}79,25+ \\
1,01^{*}\end{array}$ & $\begin{array}{c}80,00+ \\
1,41^{*}\end{array}$ & $\begin{array}{c}64,84 \pm \\
1,51^{*}\end{array}$ & $\begin{array}{c}65,10+ \\
1,56^{*}\end{array}$ & $\begin{array}{c}91,80+ \\
0,99^{*}\end{array}$ & $\begin{array}{c}95,24 \pm \\
1,42^{*}\end{array}$ & $\begin{array}{c}67,15+ \\
0,94^{*}\end{array}$ & $\begin{array}{c}65,63+ \\
1,34^{*}\end{array}$ \\
\hline
\end{tabular}

Примітка. * $(p<0,05)$ - достовірність різниці показників між групами щурів.

ВИСНОВКИ. Даний експеримент показав збільшення токсичності плазми крові у щурів за рівнем еритроцитарного індексу інтоксикації при внутрішньом'язовому введенні метотрексату.

Одноразове використання метотрексату призводить до достовірного збільшення рівня токсичності плазми крові у щурів. Дворазове введення метотрексату погіршує еритроцитарний індекс інтоксикації. Використання кальцію фолінату показало достовірні результати зменшення ендогенної інтоксикації. Введення кальцію фолінату після кожної ін'єкції метотрексату дає достовірне зменшення цього показника і не залежить від одноразового чи дворазового введення цитостатика.

ПЕРСПЕКТИВИ ПОДАЛЬШИХ ДОСЛІДЖЕНЬ. На нашу думку, є перспективним оцінити в експерименті протекторну роль кальцію фолінату у функціях печінки та інших біохімічних показниках.

\section{СПИСОК ЛІТЕРАТУРИ}

1. Бодур С. Какова роль первичного метотрексата лечения внематочной беременности / С. Бодур, Р. Гвидо // Am J Obstet Gynecol. 2014. Апрель; 210 (4) :379380.

2. Почти трагедия: тяжелая метотрексат токсичность в гемодиализа пациента лечили от внематочной беременности / Н. Виллнер, С. Шторх, Т. Фадмор, Е. Шифф // Eur J Clin Pharmacol. 2014 Map; 70 (3) :261-3. DOI: 10.1007/s00228-013-1608-3. Epub 2013 26 ноября.

3. Гуриев Т. Д. Внематочная беременность / Т. Д. Гуриев, И. С. Сидорова. - М. : Практическая гинекология, 2007. - 96 с.

4. Запорожан В. М. Оперативна ендоскопія в гінекологічній клініці / В. М. Запорожан // Лікування та діагностика. - 1998. - № 1. - С.52-55.

5. Камінський В. В. Сучасні етіологічні фактори позаматкової вагітності / В.В.Камінський, Ю.О.Туренко // Буковинський медичний вісник. - 2003. T. 7, № 4. - С.176-178.

6. Метотрексат - процент успеха при прогрессирующей внематочной беременности: новая оценка / Коэн, Л. Закар, У. Джил [и др.] // Am J Obstet Gynecol. 201419 марта. PII: S0002-9378 (14).

7. Маркін С. Б. Позаматкова вагітність / С. Б. Маркін, О. О. Матвієнко, С. А. Маркін. - Львів, 1999. - 106 c.
8. Отри А. М. Медикаментозное лечение внематочной беременности: есть ли что-то новое? / А. М. Отри // Obstet Gynecol. 2013 октябрь; 122 (4) :733-4. DOI: 10.1097.

9. Внематочная беременность / А. Н. Стрижаков, А. И. Давыдов, М. Н. Шахламова, Л. Д. Белоцерковская. - М. : Медицина, 1998. - 201 с.

10. Сяо С. Влияние метотрексата для лечения внематочной беременности на состояние овариального резерва / С. Сяо, М. Н. Даан // Fertil Steril. 2014 Апрель; 101 (4): е23.

11. Системное использование метотрексата: эффективная альтернатива хирургии для лечения неразвивающейся внематочной беременности / P. Тальвар, К. Сандип, N. Naredi [и др.] // Med J Booруженные силы Индии. 2013 Апрель; 69 (2) :130-3

12. Baldvinsdottir Сортировка, Гудмундссон JA, Geirsson PT. Заболеваемость и управление внематочной беременности в Исландии 2000-2009 // Laeknabladid. 2013.-12.-; 99 (12) :565-70.

13. Association of plasma leptin, homocysteine and nitric oxide levels with the presence and unstability of coronary artery disease / G. Basati, A. E. Razavi, S. Abdi, N. Sarrafzedegan // Biomark Med. - 2014. - Vol. 8(3). - P. 405-412. doi: 10.2217/bmm.13.131.

14. Seremak-Mrozikiewicz A. Metafolin-alternative for folate deficiency supplementation in pregnant women / A. Seremak-Mrozikiewicz // Ginekol. Pol. - 2013. Vol. 84(7). - P. 641-646. Review. Polish. 